This article was downloaded by: [Australian National University Library]

On: 8 June 2010

Access details: Access Details: [subscription number 907447645]

Publisher Routledge

Informa Ltd Registered in England and Wales Registered Number: 1072954 Registered office: Mortimer House, 3741 Mortimer Street, London W1T 3JH, UK

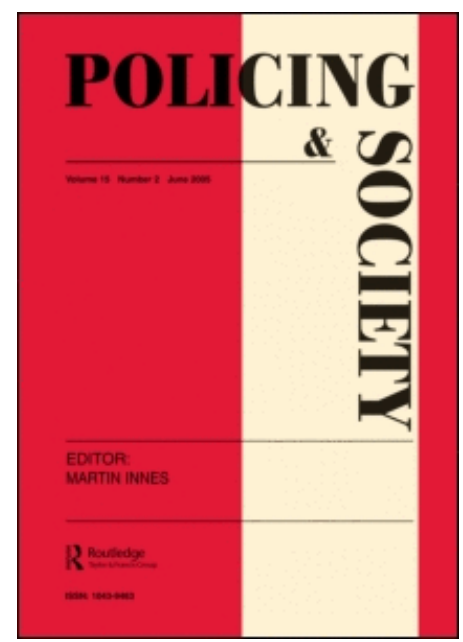

\title{
Policing and Society
}

Publication details, including instructions for authors and subscription information:

http://www.informaworld.com/smpp/title content=t713646669

Networks and Meta-regulation: Strategies Aimed at Governing Illicit Synthetic Drugs

Adrian Cherney; Juani O'Reilly; Peter Grabosky

To cite this Article Cherney, Adrian, O'Reilly, Juani and Grabosky, Peter(2006) 'Networks and Meta-regulation: Strategies Aimed at Governing Illicit Synthetic Drugs', Policing and Society, 16: 4, 370 - 385

To link to this Article: DOI: $10.1080 / 10439460600973693$

URL: http://dx.doi.org/10.1080/10439460600973693

\section{PLEASE SCROLL DOWN FOR ARTICLE}

Full terms and conditions of use: http://www.informaworld.com/terms-and-conditions-of-access.pdf

This article may be used for research, teaching and private study purposes. Any substantial or systematic reproduction, re-distribution, re-selling, loan or sub-licensing, systematic supply or distribution in any form to anyone is expressly forbidden.

The publisher does not give any warranty express or implied or make any representation that the contents will be complete or accurate or up to date. The accuracy of any instructions, formulae and drug doses should be independently verified with primary sources. The publisher shall not be liable for any loss, actions, claims, proceedings, demand or costs or damages whatsoever or howsoever caused arising directly or indirectly in connection with or arising out of the use of this material. 


\title{
Networks and Meta-regulation: Strategies Aimed at Governing Illicit Synthetic Drugs
}

\author{
Adrian Cherney, Juani O’Reilly \& Peter Grabosky
}

New regulatory state scholarship has documented the rise of pluralized forms of governance that lay beyond central states. This has resulted in regulation being constituted by dense networks of actors and institutions. This article sets out to explore the role of police agencies within these networks through a case study of illicit synthetic drug control. Reducing the supply of illicit synthetic drugs presents unique challenges for the police compared to the control of traditional plant-based illicit drugs such as cannabis or heroin. A key focus of reducing supply is that of governing the interface between licit and illicit market activities. This strategy has required police agencies to increasingly engage in forms of meta-regulation. Under such a strategy, the police role is increasingly one of acting as "brokers" i.e., connecting the internal capacity of external institutions to crime control goals and promoting collective responses around externalities (i.e., opportunities for illegal conduct) generated by legitimate commercial activity.

Keywords: Illicit synthetic drugs; Policing; Networks; Meta-regulation; Leveraging

\section{Introduction: The Changing Face of Regulation and Policing}

There is little doubt that processes of regulation are increasingly the result of complex interactions between the state, markets, the private sector and civil society (Parker \& Braithwaite, 2003). This is supported by "new regulatory state" scholarship that has documented the rise of pluralized forms of governance that lie beyond central states and has set out to identify how these new forms of governance can be enhanced

\footnotetext{
Adrian Cherney is a Lecturer at the School of Social Science at the University of Queensland. Juani O'Reilly is a Federal Agent of the Australian Federal Police. Peter Grabosky is a Professor in the Regulatory Institutions Network at the Australian National University. Research for this article was undertaken when Adrian Cherney was a post-doctoral fellow in the Regulatory Institutions Network, Security 21, Australian National University. Correspondence to: Adrian Cherney, School of Social Science, University of Queensland, St Lucia 4072, Australia. E-mail: a.cherney@uq.edu.au
} 
(Braithwaite, 2000; Braithwaite \& Drahos, 2000; Grabosky, 1995a; Dupont, 2004; Shearing, 1993). One of the key conclusions of this work is that regulation is constituted by dense networks of actors and institutions, and a key aim of central state regulation is increasingly one of co-opting and forming alliances with non-state orderings. This has led scholars to argue that this form of regulation is best characterized as "meta-regulation" - that is, central states and its organs (authorities) over-sighting and facilitating plural regulatory practices within various private and public settings (Grabosky, 1995a: 543; Parker, 2002: 15; Parker \& Braithwaite, 2003: 141). ${ }^{1}$ It is also recognized that policing as a process has become dispersed among networks, with the provision of security now authorized and delivered by a range of auspices and providers that lay within and external to the central state (see Dupont, 2004; Dupont et al., 2003; Johnston, 2000). This body of work further supports conclusions made by new regulatory state scholarship that there now exists an increasing pluralization of activity mobilized against specific problems of governance.

While this body of work has documented the diversification of different dimensions of governance concerned with regulation and security, an important question in need of further clarification is what is the role of the public police within these emerging networks of governance. Answering this empirical question is important because the trends documented above clearly have implications for police policy and practice. Also the possibility cannot be overlooked that police organizations have actively contributed to the emergence of dispersed networks of governance because of the strategic benefits such activities provide in assisting them to fulfill core functions. In this article we wish to explore this question by examining the ways in which police agencies are seeking to enhance the capacities of external institutions in furtherance of reducing the supply of illicit synthetic drugs (i.e., amphetamine-type substances). Our use of the term "police agencies" denotes far more than just the public police and incorporates bodies such as customs agencies who have an important "policing" role in the modern "security assemblage", their role becoming more significant in the context of the "new terrorist threat". We will use the case study of illicit synthetic drug control to illustrate that the role of police agencies within "networks" is increasingly one of acting as "brokers" - that is, connecting the internal capacity of external institutions to crime control goals and promoting collective responses around externalities (i.e., opportunities for illegal conduct) generated by legitimate commercial activity. Our argument is that this facilitation and leveraging of third parties is occurring through strategies of governance that closely resemble forms of meta-regulation.

Before beginning to flesh-out these arguments, we wish to provide some points of clarification. First, we recognize that the analysis we provide may not be applicable across all jurisdictions. Many of the examples we employ are taken from Englishspeaking countries; however, there are some "globalizing" tendencies relating to the ways in which the policing of illicit synthetic drugs has become multi-lateralized through the rhetoric of partnerships (Cherney et al., 2004a, 2004b, 2005, 2006). We realize that the issues canvassed below overlap and are relevant to other areas of illicit 
drugs such as heroin and cocaine. However, policing illicit synthetic drugs presents unique challenges that are quite distinct from more traditionally trafficked illicit drugs such as cannabis, heroin or cocaine. What these challenges are will become clearer below. Briefly, they relate to the fact that the manufacture of illicit synthetic drugs relies heavily upon the existence of lawful enterprise and that such drugs are far easier to produce compared to cannabis, heroin or cocaine.

We do not wish to engage in debates over the merits of supply reduction versus demand or harm reduction. These are debates for another time. We do not dismiss the importance of demand or harm reduction to an overall holistic approach to drug control. In fact, many of the approaches discussed in this article that have the explicit goal of reducing supply also have secondary goals of minimizing harm (e.g., tackling the problem of clandestine drug laboratories also aims to minimize individual and public risks associated with illicit manufacture) (Cherney, 2005). Debates over the merits of, and compatibility between, supply, demand and harm reduction have been well rehearsed in the literature (see Canty et al., 2001). ${ }^{2}$ Our focus is on approaches that emphasize supply reduction through pluralized forms of policing, and we use the case study of illicit synthetic drugs to highlight how police agencies and governments have been active in reconfiguring and structuring the nature of policing through particular strategies of governance. Such developments should not be regarded as unproblematic; we examine weaknesses of these trends to illustrate that pluralized forms of policing are not without their unintended (potentially negative) consequences.

\section{Policing Illicit Synthetic Drugs}

When using the term "illicit synthetic drugs" we are referring to drugs that are solely produced and derived from chemical synthesis and do not rely upon harvested crops for their manufacture such as heroin and cannabis. While there is a wide spectrum of drugs that can be classified as synthetic, for the basis of this article we are referring to amphetamine-type substances (ATS), including amphetamine (speed), methamphetamine (ice, crystal meth) and MDMA (ecstasy). Both terms unless specified will refer to these three main synthetic drugs.

While cannabis remains the most popular illicit drug globally, illicit synthetic drugs are now the most used and seized illicit drug worldwide after cannabis, with methamphetamine constituting the bulk of global seizures (Office on Drugs and Crime, 2003, 2004). Research on illicit synthetic drug production in Eastern Europe, Australia, New Zealand, North and South America, and the Asia Pacific region all point to increasing numbers of clandestine laboratories manufacturing ATS, with evidence indicating that its production is actually beginning to outstrip the global production of cannabis and heroin (ACC, 2003; Bureau for International Narcotics and Law Enforcement Affairs, 2004; DEA, 2003a, 2003d; International Narcotics Control Board, 2004; New Zealand Customs Service, 2002; Office on Drugs and Crime, 2003, 2004). The reason for the rise in the manufacture of ATS can be 
attributed to a number of factors: profitability in manufacture and trafficking given input costs compared to outputs (i.e., low production costs relative to the size of the product produced and its wholesale price); the various and simple synthetic routes to manufacture the end product; and easy access to a variety of essential starting materials (DNE, 2003; Gordon, 2001; Office on Drugs and Crime, 2003; UNCDP, 1996; Wilkins, 2002).

In contrast to more traditional drugs like cocaine, heroin or cannabis, the production of illicit ATS is comparatively simple. It requires fewer inputs compared to cultivated drugs of a natural origin and is far easier to transport; their light weight allows large amounts to be trafficked (DNE, 2003). Also rather than relying upon the use of sophisticated smuggling routes to traffic the illegal drug, clandestine drug laboratories can be established close to consumer markets with the necessary chemicals very easy to source locally. The manufacture and supply of illicit synthetics is unlike cannabis and heroin given that ATS have a double supply side system: diversions from licit pharmaceutical and chemical trade, as well as illicit manufacture (Chawla, 1998). It is the interface between licit environments and illicit production of ATS that compounds efforts to control illicit synthetic drugs, given their manufacture is reliant upon the existence of lawful enterprise.

The manufacture of ATS requires a range of chemical precursors, reagents and solvents, all of which can be legally purchased from a local chemist, hardware store and commercial chemical distributors. For example, a key precursor - the most important - used in the production of methamphetamine is ephedrine or pseudoephedrine, found in cold and flu tablets and nasal decongestants. The Birch (Nazi) method of methamphetamine production utilizes lithium (as well as sodium metal) as a reagent; the lithium metal extracted from batteries. This technique also uses anhydrous ammonia, a crop fertilizer and air conditioner refrigerant. Red phosphorus is used in the "red-p method"; the red phosphorous extracted from match heads or the sticker plates of matchboxes. Other chemicals also used include acetone, brake cleaner, camping fuel, iodine crystals, propane, rock salt and toluene (i.e., paint thinner). Along with the necessary equipment such as glass jars, bottles, plastic tubing, coffee filters, baking dishes, hotplate, strainers and propane tanks, a "meth cook" can easily set up their own clandestine laboratory in a range of environments such as rental properties, motel rooms, sheds, rural areas and even the trunk of a car. Such small-scale laboratories (referred to as "boxed labs", "boot labs" or "mom and pop" labs) are highly mobile and difficult to detect (ACC, 2003; Castellano et al., 2003; International Narcotics Control Board, 2004; McEwen et al., 2002; National Drug Intelligence Center, 2003; Office on Drugs and Crime, 2003; DEA, 2000, 2003c,n.d.B). ${ }^{3}$

The manufacture of ecstasy, while a little more complicated compared to methamphetamine, is no less reliant upon licit products and lawful enterprise. For example, the chemical precursors essential to ecstasy production include safrole oil used in perfumes and soaps (International Narcotics Control Board, 2004; UNCDP, 1996). The equipment required for ecstasy production all has industrial uses and can 
be purchased directly from legitimate commercial manufactures and suppliers (e.g., tabletting machines essential to the final phase of ecstasy production are used in the pharmaceutical and confectionary industry).

Given the double supply side nature of the illicit synthetic drug market and the clear interface between licit environments and the production of ATS, reducing the supply of illicit synthetic drugs needs to focus on tackling the situational conditions that provide opportunities for illicit manufacture to occur (e.g., large quantities of pseudoephedrine at retail levels, lax "Know Your Customer" policies at wholesale levels, the lack of mandatory thresholds on the sale of cold and flu medication, or deficient import or export monitoring systems on precursor chemicals). Given that ATS have a double supply side system, one effective strategy is to focus on key "factors of production" - that is, those factors within the ATS supply chain that can be most readily made scarce relative to others (Kleiman \& Young 1995). Given the reliance of the illicit synthetic drug market upon chemicals and licit industries, preventing diversion into illicit markets is an important method of impacting on significant "factors of production" that affect ATS supply. Diversion control acts like a direct tax on ATS trafficking by increasing operational cost suppliers face (e.g., acquiring the chemicals necessary for manufacture) that can have corresponding impacts upon levels of both supply and demand (Dorn et al., 2003; Kleiman \& Young, 1995). Not only is the diversion of chemicals into illicit markets a key "factor of production" vulnerable to disruption, but it also encompasses infrastructure such as transport facilities, financial systems or technology that provide opportunities for manufactures and traffickers to exploit licit environments for illicit purposes (Dorn et al., 2003; Van de Bunt \& Van der Schoot, 2003).

So what is the relevance of the above discussion to the changing face of governance, regulation and policing? This will become clear as we begin in the next section to explore the ways in which the governance of illicit synthetic drugs is expressed at a programmatic level through various policy proscriptions, regulatory regimes and institutional practices. Doing so requires us to examine how police agencies are engaging external institutions and actors in furtherance of reducing the supply of ATS. What is significant about the interface between licit and illicit markets and the ways in which it determines illicit synthetic drug markets is that policing this interface has required forms of "governance" that emphasizes processes of coordination, steering, influencing and balancing interactions of public and private groups (Edwards \& Gill, 2002), rather than the direct processes of sovereign government that are based on punitive responses often associated with illicit drug control (i.e., interdiction). Examining the various technologies of governance being adopted by police agencies to "police" the interface between licit and illicit markets as they pertain to the control of illicit synthetic drugs tells us much about the changing role of the public police within networks of governance. 


\section{Governing the Supply of Illicit Synthetic Drugs}

In this section, we outline the types of institutional arrangements and mechanisms being adopted by police agencies to govern the interface between licit environments and the manufacture and trafficking of illicit synthetic drugs. The practices have been categorized under five broad headings, the typology adopted from Grabosky's (1995a, 1996) work on hybrid governance (also see Cherney et al., 2005). These different mechanisms overlap and should be understood as complementary complianceseeking strategies that rely upon formal and informal contractual arrangements to compel and persuade interested parties to adopt some level of preventative action. Importantly, they draw upon the capacities of entities to regulate their own activities through tactics that aim to "responsibilize" third parties both directly through "command and control" regulation (i.e., use of the law) and indirectly through systems of enforced self-regulation (Hutter \& Power, 2000; Hutter, 1997, 2001). ${ }^{4}$ Such approaches can lead to effective risk management by influencing the dynamics of particular market activities that have a bearing upon levels of unlawful behaviour (Hutter, 1997, 2001). This is important in the context of illicit synthetic drug control given certain market activities (i.e., pharmaceutical and chemical trade) are characterized by levels of risk by virtue of the opportunities they provide for illegal activity to occur. The result is pluralized systems of ordering in which police form part of a broad network of agencies that aim to shape ATS markets through diversion control strategies. In descending order on the basis of coerciveness, such practices include the following strategies: conscription, required record keeping and disclosure, conferring entitlements, co-optation of external interest (private and public sector), and incentives.

\section{Conscription}

This is perhaps the most direct way by which police agencies have engaged third parties to assist in processes of supply reduction. It involves mandating third parties through such mechanisms as legislative and mandatory provisions to carry out certain functions. In the United States, for example, chemical companies who produce and sell listed chemicals that can be used in the manufacture of ATS are required by law to report to the Drug Enforcement Administration (DEA) the sale of "above threshold quantities" of these chemicals (see DEA, 2004b). Similar arrangements exist in the Netherlands where the Economic Control Service (i.e., FIOD-ECD, who has enforcement responsibility for controlling the diversion of precursor chemicals into illicit production of, mainly, ecstasy) imposes similar requirements on the chemical industry (see Cherney et al., 2005).

Many American states have passed or are proposing new laws that require pharmacies and retail stores to put in place procedures to prevent diversion. This includes how products such as pseudoephedrine are displayed and their location behind the counter, the number of packets that can be sold at one time and the 
security of products in store (Clanton Advertiser, 2004; Dallas Morning News, 2004; Peoria Journal Star, 2004). Likewise this responsibilization has been extended to owners of environments whose facilities and infrastructure are used to aid and conceal either the production or trafficking of illicit synthetic drugs. One such example is the Clandestine Drug Laboratory Remediation laws adopted by the state of Arizona that places a legal onus on property owners, whose premises or property have been used in the production of methamphetamine, to pay for the clean up of the property and its remediation. ${ }^{5}$ A direct aim of such laws is to facilitate greater vigilance on the part of third parties to oversight and monitor environments. They impose legal obligations on bodies whose legitimate business facilitates conditions and opportunities necessary for the production or trafficking of illicit synthetic drugs.

\section{Required Record Keeping and Disclosure}

A number of jurisdictions require that transactions of listed chemicals used in the production of ATS be recorded and that records be kept for a defined period. Such processes of enumeration, record keeping and disclosure have an important regulatory function by subjecting records to possible public scrutiny and enhancing vigilance on the part of third parties. Again, both in the United States and the Netherlands, companies are required to keep records of transactions of listed chemicals for a defined period and these records must be made available for examination to both the DEA and FIOD-ECD, respectively.

\section{Conferring Entitlements}

This involves the development of new entitlements or the use of pre-existing ones to induce and persuade third parties to undertake some form of action. Such provisions are not compulsory, but provide the opportunity and capacity for third parties to take action. This can involve the creative use of civil remedies or administrative action undertaken by third parties on behalf of the state and has been referred to as "third party" policing (Mazerolle \& Ransley, 2005). Civil remedies have been particularly effective in the prevention and reduction of neighbourhood disorder associated with drug use. The use of civil remedies was adopted by the Oakland's Beat Health Program in California to reduce the impact of illicit drugs on local neighbourhoods (Mazerolle et al., 1998). The program focused on the physical decay and property management conditions. Police encouraged housing authorities and residents to use municipal regulations and health and safety codes against landowners whose property was providing the cover for the production or trafficking in illicit drugs. The use of civil remedies was also adopted under the Salt Lake City Methamphetamine Initiative as a way of reducing the impact of methamphetamine on local neighbourhoods. While this was the least utilized component of the Salt Lake City strategy, ${ }^{6}$ the aim was to take action against owners whose property was 
providing the environment and cover for methamphetamine manufacture and trafficking (Castellano et al., 2003).

\section{Co-optation of External Interest (Private and Public Sector)}

In some settings, police agencies can actively seek the cooperation of private interests in furtherance of surveillance and detection. In doing so, the roles of private institutions can be redefined in accordance with their functional abilities to prevent the occurrence of illegal activities. Much of this cooperation can be facilitated through a range of mechanisms and administrative tools that broaden the duties of intermediaries who play important "gatekeeper" roles between licit and illicit environments. For example, in the Australian state of Victoria, police have instituted a Pharmacy Watch Program to alert chemists to the risk of thefts of cold and flu preparations (ACC, 2003; Victorian Drugs and Crime Prevention Committee, 2004). Key designated positions (known as "chemical diversion desks") have been created within Australian police service to seek cooperation from the private sector and develop protocols with industry to identify suspicious transactions and the purchase of multiple packets of pseudoephedrine products. Similar roles exist in the DEA in the United States with diversion investigators administering regulatory and administrative controls on precursor chemicals that involve the use of facilitative mechanisms of co-optation (see Cherney et al., 2005).

Co-optation can be less direct, achieved through techniques of persuasion that encourage third parties to take action that obstructs and stymies misconduct. For example, the DEA's Office of Diversion Control operates a "Warning Letter Program" in which manufacturers and distributors of precursor chemicals such as pseudoephedrine and ephedrine are notified when their product is found in a clandestine drug laboratory. These letters can form the foundation for further action against manufacturers and distributors if evidence emerges that diversion is continuing, or if no action has been undertaken on the part of the licensed registrant to limit its occurrence. The overall aim of the programme though is to avoid such outcomes, the underlying tactic being to coax cooperation before escalating to more punitive responses. Similar approaches have been adopted by Dutch authorities (i.e., FIODECD) (Cherney et al., 2005).

Co-optation can also occur through the police and industry mutually developing voluntary codes of conduct. Such codes aim to build organizational integrity by encouraging industry members to oversee their commercial practices. For example, in Australia, a national code of practice has been developed between Victoria police and industry associations pertaining to the control of precursor chemicals (see Victorian Drugs and Crime Prevention Committee, 2004). Such standards can be given official status by public agencies and result in authorities actually expanding their level of oversight by facilitating self-regulation on the part of third parties. This process of deference and a willingness on the part of law enforcement to relinquish certain 
"policing" duties to third parties has been important in creating the conditions necessary for pluralized forms of policing to become possible.

One of the best examples that has resulted in policing functions becoming dispersed through networks is the Memoranda of Understanding (MOU) programme established by the World Customs Organization (WCO) aimed at the transportation of illicit drugs. A key aim of this strategy has been to address the diversion and smuggling of precursor chemicals through legitimate transportation routes and the use of commercial infrastructure for this purpose. Known as the "Action/Defis Program", it has involved the WCO developing an action plan to mobilize customs authorities worldwide to establish MOU programmes with their national transport carriers and relevant businesses. ${ }^{7}$ The MOU is an agreement negotiated between customs administrations and relevant trade associations and private-sector companies. In the context of governance, MOUs are mechanisms that activate the necessary processes and practices through which "responsiblization" is orchestrated. Put more simply, they are basically guidelines that cover such areas as intelligence and information exchange, enhancing security measures among the private sector, and provision of training to key personnel of carrier companies to identify potential threats and undertake risk assessments. The MOUs are not legally binding contracts nor are they enforceable, but they do create the conditions under which both privateand public-sector bodies work to police the interface between legitimate commercial activities and illicit trade (Schneider et al., 2000; Van de Bunt \& Van der Schoot, 2003). Many national MOU programmes have been introduced by various national customs agencies, ${ }^{8}$ including, for example, the United Kingdom Customs Anti-Drug Alliance programme that focused on addressing the diversion of precursor chemicals through targeting the import/export industry, including shipping lines, port authorities and airport corporations (see Cherney et al., 2005).

\section{Incentives}

Governments and public police agencies can offer incentives directly to the targets of regulation so as to induce compliance with desired conduct. For example, rewards may be offered to third parties for information in furtherance of investigation and prosecution. The use of "carrots" (i.e., rewards) as a regulatory instrument can be employed in a range of settings and is potentially more effective in inducing sustained compliance over the long term compared to coercion (Ayres \& Braithwaite, 1992; however, see Grabosky, 1995b). This can apply to the area of illicit drugs, with incentives a viable method of encouraging cooperation from third parties such as commercial industry. For example, this can include the reduction of regulatory burdens as a result of cooperation and does not have to be limited to financial rewards, but can include outcomes such as increased interaction among partnership members that has commercial benefits such as increased productivity. For instance, one industry partnership programme that the United States Bureau of Customs and 
Border Protection is implementing provides for reduced examinations of shipments (Cherney et al., 2005).

\section{Governing Illicit Synthetic Drugs through Meta-regulation and Networks}

What has been outlined is a mix of governance strategies aimed at controlling illicit synthetic drugs - some are direct formal arrangements, others aim to co-opt action, while some rely upon developing spontaneous action within the private sector and civil society. What is significant is that rather than relying upon direct processes of governance such as punitive enforcement by the sovereign state, these processes aim to steer, influence and balance interactions of public and private groups. They in particular aim to enhance the self-regulatory capacity of external institutions to take action against supply side factors that influence the production of illicit synthetic drugs. In essence, they epitomize meta-regulation: they are solely not state regulation nor solely reliant upon market orderings, but are strategies of plural regulation. All are characterized by the common aim of regulating the boundary between the manufacture of illicit drugs and "access points" (i.e., legitimate business and industry activity) that provide opportunities for ATS production.

What is significant is that police agencies have not remained passive agents in shifts towards pluralized forms of policing. They have, through the use of particular mechanisms (strategies of meta-regulation), informed and shaped these developments. This in particular highlights a key role of police agencies within networks: one of brokering alliances with external agencies. In this regard, authorities of the state have been the active creator of policing networks. This is exactly what is happening in the area of illicit synthetic drug control.

The analysis of illicit synthetic drug control illustrates that changes being witnessed more broadly around state regulation in which central governments seek to broker relationships with regulated entities (Hutter \& Power, 2000; Hutter, 2001) can also be accorded to an understanding of the police role within emerging networks of governance. A key responsibility within these structures has been to help connect the internal capacity of external institutions to crime control goals (i.e., by impacting on key factors of production in the ATS supply chain) and in promoting collective responses to the possible externalities (i.e., opportunities for illegal conduct) that legitimate commercial activities can generate. In many ways, the very aetiology of illicit synthetic drug production and market supply - the fact it relies on an interface between legal and illegal activity and diversion of licit products - has required the police to assume these facilitative roles and adopt varying strategies of governance to control such criminal activities.

Of course shifts toward networked forms of policing are not without their weaknesses or potential unintended consequences, particularly in the area of illicit drug control. Such developments should not be seen "through rose-tinted glasses". Notwithstanding the general concerns about such developments "widening the net of social control" (Johnston, 2000; Lint, 2003) or that they comprise attempts by state 
authorities to "rule at a distance" (O’Malley, 1992; Rose \& Miller, 1992), such critical assessments need to be based on an understanding about the specific problems particular policing networks set out to address. In the context of illicit synthetic drugs, control mechanisms that emphasize third party policing processes and broaden the range of agencies involved in supply reduction programmes can inevitably lead to illicit markets adapting to such interventions. This can involve criminal syndicates or individuals (e.g., methamphetamine cooks) seeking out new precursors or finding alternative avenues of manufacture (Cherney et al., 2005). The unintended consequence can be a shift in illegal diversion activities to vulnerable "access points" within licit markets - for example, away from large wholesale and retail companies who deal in chemicals and equipment necessary for ATS production to smaller businesses at the retail levels who may lack capacities and resources required to participate as effective partners within policing networks. Hence any assessment of the outcomes of policing networks needs to consider the capacity of third parties to participate directly because this dictates their overall effectiveness. It also determines if there has been any substantive dispersal of policing functions away from central authorities. In addition, an unintended consequence of policing networks is that they can displace the very crime and safety problems they aim to address. On a positive note, this latter consequence is not always inevitable (e.g., see Hesseling, 1994).

At a strategic and tactical level, various techniques being employed to govern illicit synthetic drugs do have limitations. They are particularly effective at disrupting certain features (i.e., particular hubs of activity) within ATS markets that are susceptible to high levels of redundancy and easily replaceable. For example, they are effective at undermining the capacity of small operators of clandestine drug laboratories and "pseudo runners"9 (Cherney et al., 2005). However, other hubs of activity within ATS markets, such as the involvement of organized crime, are perhaps more resilient and have the capacity to undermine these various governance arrangements. For example, organized crime groups can provide financial and logistical support to establish fictitious chemical companies as a means of diverting chemicals. This is not to say that the various mechanisms outlined above are ineffective; rather it signifies that shifts towards pluralized forms of policing and the rise of the "new regulatory state" that has facilitated such developments should not be taken as unproblematic. This becomes evident when one begins to analyze more closely the types of strategies that policing networks adopt and the problems they target.

\section{Conclusion}

In this article, we have shown how policing as a processes has changed significantly and described the role of police agencies within emerging networks of governance. Such an analysis as attempted here is important in unlocking the diversity of practices that have coalesced around networked policing and in identifying potential problems 
with such trends. In the context of illicit synthetic drug production, there exists a high degree of interface between legal and illegal activity. Hence, it is not surprising that supply reduction efforts aimed at ATS are constituted of a mix of complianceseeking strategies that seek to control particular market activities (i.e., significant factors of production), which can have a corresponding impact on levels of supply. What we see is police agencies adopting forms of meta-regulation: governance strategies that are constituted of interactions between formal directed regulation (conscription, record keeping, etc.), indirect and facilitated actions (e.g., co-optation of external interests, conferring entitlements, etc.), and self-regulation (delegation or deference to private parties).

The result of all this activity is that policing the supply of illicit synthetic drugs is constituted of dense assemblages or networks. While sites and agencies within these networks may to a large degree be autonomous entities, they do relate to one another in varying ways across time and space by coalescing around a common goal. Within this particular form of networked governance, the police act as brokers: co-opting and forming alliances with intermediaries, third parties and non-state orderings by using different instruments of governance to reduce the supply of illicit synthetic drugs. Just as definitions of state regulation have changed significantly, so too must conceptions of the roles police agencies assume under emerging networks of governance.

\section{Notes}

[1] Parker and Braithwaite (2003: 141) describe meta-regulation as "government regulation of plural regulation in the private sector and civil society". Parker $(2002: 15,246)$ regards it as "regulating the regulators" in which the state withdraws from attempting to be the direct agent of command and control and public management in favour of being an indirect regulator of internal control systems in both public and private agencies. It is these techniques of governing and facilitating such non-state orderings that are seen as comprising "meta-regulation" (also see Grabosky, 1995a).

[2] This article does not canvass the health consequences of illicit synthetic drug use or the effects of addiction. Again research has focused extensively on these issues (see Victorian Drugs and Crime Prevention Committee, 2004).

[3] These clandestine laboratories pose significant human and environmental threats. The waste from ATS production is highly toxic and flammable. Fumes can cause serious injury such as eye, skin or respiratory damage, or in some cases even death. Harmful fumes produced include phosphine gas, hydrogen cyanide and hydrogen sulphide. The amount of waste produced by synthetic drug production is enormous. It is estimated that the production of one kilogram of amphetamine or ecstasy will, depending on the production method, result in 5-20 litres of waste. Much of this waste seeps into the surrounding environment and poses significant clean up costs and ongoing hazards (DEA, 2003c: 71, 73, n.d.A; National Drug Intelligence Center, 2003; McKwen et al., 2002; Scott, 2002; Steel, 2003).

[4] Such a tactic has been aided by central states' efforts to institute shifts in governance by recalibrating their roles in relation to the development and implementation of policy (i.e., steering more, rowing less; see Osborne \& Gaebler, 1992). This has seen an emphasis on policies and programmes that aim to transfer the task (i.e., the management of risk) for dealing with safety and security onto institutions, groups and individuals within the private 
sector and civil society. Such a strategy of responsibilization has been identified as a key characteristic of the new regulatory state (Crawford, 2004; Garland, 2001).

[5] See http://www.ag.state.az.us/DEC/EnviroImpact.html

[6] This was due to misunderstandings about the ambit of civil nuisance abatement laws and a lack of communication between relevant authorities and participants in the Salt Lake City strategy over their use.

[7] For more information, see http://www.wcoomd.org/.

[8] See http://www.wcoomd.org/.

[9] "Pseudo runners" is a termed used to refer to individuals who target retail-level pharmacies and purchase multiple packets of cold and flu medication for the purpose of diverting it into illicit markets.

\section{References}

Australian Crime Commission (ACC) (2003), Australian Illicit Drug Report, 2001-2002, ACC, Canberra.

Ayres, I. \& Braithwaite, J. (1992), Responsive Regulation, Oxford University Press, New York.

Braithwaite, J. (2000), "The new regulatory state and the transformation of criminology", British Journal of Criminology, Vol. 40, no. 2, pp. 222-238.

Braithwaite, J. \& Drahos, P. (2000), Global Business Regulation, Cambridge University Press, Cambridge.

Bureau for International Narcotics and Law Enforcement Affairs (2004), International Narcotics Control Strategy Report: 2003, US Department of State, Issued March 2004. Available online at: http://www.state.gov/g/inl/rls/nrcrpt/ (accessed 13 December 2004).

Canty, C., Sutton, A. \& James, S. (2001), "Models of community-based drug law enforcement", Police Practice and Research, Vol. 2, no. 3, pp. 171-187.

Castellano, T., et al. (2003), An Evaluation of the COPS Office Methamphetamine Initiative, Office of Community Orientated Policing Services, US Department of Justice, Washington, DC.

Chawla, S. (1998), “They're clandestine. They can heal. They can kill”, United Nations Chronicle, Vol. 35, no. 2, pp. 34-35.

Cherney, A. (2005), The Problem of Clandestine Drug Labs: International Experience and Tackling Illicit Synthetic Drug Manufacture Through Co-Production. Paper presented at the Australian and New Zealand Society of Criminology 18th Annual Conference, Crime Community and the State, 9-11 February, Wellington.

Cherney, A., O’Reilly, J. \& Grabosky, P. (2004a), International Experience in Chemical Diversion and Control: The Case of Illicit Synthetic Drugs. Paper presented at the 8th National Chemical Diversion Congress, Achieving Supply Reduction through Partnerships and Education, 19-21, October, Melbourne.

Cherney, A., O’Reilly, J. \& Grabosky, P. (2004b), The Governance of Illicit Synthetic Drugs. Paper presented at the Australian Institute of Criminology Conference, Crime in Australia: International Connections, 29-30 November, Melbourne.

Cherney, A., O’Reilly, J. \& Grabosky, P. (2005), The Governance of Illicit Synthetic Drugs. Project report funded by National Drug Law Enforcement Research Fund and the Australian Federal Police, National Drug Law Enforcement Research Fund, South Australia.

Cherney, A., O'Reilly, J. \& Grabosky, P. (2006), “The multilateralization of policing: The case of illicit synthetic drug control", Police Practice and Research, Vol. 7, no. 3, pp. 177-194.

Clanton Advertiser (2004), "US AL: New state law aimed to curb meth cookers", Clanton Advertiser, 5 September. Available online at: http://www.mapinc.org/drugnews/v04.n1272.a04.html (accessed 13 December 2004).

Crawford, A. (2004), "Contractual governance of deviant behaviour", Journal of Law and Society, Vol. 30, no. 4, pp. 479-505. 
Dallas Morning News (2004), "Methbusters: Simple laws restrict supply for labs", 22 August. Available online at: http://www.mapinc.org/drugnews/v04.n1200.a06.html (accessed 13 December 2004).

Dirección Nacional de Estupefacientes (DNE) (2003), Columbia's War Against Drugs: Actions and Results 2002, DNE, Bogota. Available online at: http://www.dnecolombia.gov.co/doc/ Publicaciones/estrategica/Libro_Blanco02ingles.pdf

Dorn, N., Bucke, T. \& Goulden, C. (2003), "Traffic, transit and transaction: A conceptual framework for action against drug supply", Howard Journal, Vol. 42, no. 4, pp. 348-365.

Drug Enforcement Administration (DEA) (2000) Chemicals Used in the Clandestine Production of Drugs, Drug Enforcement Administration, Office of Diversion Control, Drug and Evaluation Section, US Department of Justice, Washington, DC (unpublished document).

Drug Enforcement Administration (DEA) (2003a), The Methamphetamine Situation in the United States, DEA Intelligence Division, Washington, DC.

Drug Enforcement Administration (DEA) (2003b), Drugs of Abuse, DEA, US Department of Justice, Arlington, VA.

Drug Enforcement Administration (DEA) (2003c), Microgram Bulletin, Vol. 36, no. 4. Available online at: http://www.dea.gov/programs/forensicsci/microgram/index.html

Drug Enforcement Administration (DEA) (2003d), Facing the Methamphetamine Problem in America. Statement of Rogelio E. Guevara, Chief of Operations, DEA, before the House Committee on Government Reform, Subcommittee on Criminal Justice, Drug Policy and Human Resources, 18 July.

Drug Enforcement Administration (DEA) (2004b), Chemical Handlers Manual: A Guide to Chemical Control Regulations, Drug Enforcement Administration, US Department of Justice, Washington, DC.

Drug Enforcement Administration (DEA) (n.d.A), Chemical Diversion and Synthetic Drug Manufacture. DEA Intelligence Report. Available online at: http//www.usdoj.gov/dea/pubs/ intel/intel010621p.html

Drug Enforcement Administration (DEA) (n.d.B), Clandestine Laboratory Awareness. Pamphlet produced by the DEA, Clandestine Laboratory Enforcement Team, US Department of Justice, Washington, DC.

Dupont, B. (2004), "Security in the age of networks", Policing \& Society, Vol. 14, no. 1, pp. 76-91.

Dupont, B., Grabosky, P. \& Shearing, C. (2003), "The governance of security in weak and failing states", Criminal Justice: International Journal of Policy and Practice, Vol. 3, no. 4, pp. 331349 .

Edwards, A. \& Gill, P. (2002), "Crime as enterprise? The case of transnational organised crime", Crime, Law and Social Change, Vol. 37, no. 3, pp. 203-223.

Garland, D. (2001), The Culture of Control: Crime and Social Order in Contemporary Society, Oxford University Press, Oxford.

Gordon, S. (2001), "Technology impacts on drug production in Asia: The role of amphetamines in Asia’s growing drug problem”, Platypus Magazineno, Vol. 72, pp. 17-22.

Grabosky, P.N. (1995a), "Using non-governmental resources to foster regulatory compliance", Governance, Vol. 4, no. 8, pp. 527-550.

Grabosky, P.N. (1995b), "Regulation by reward: On the use of incentives as regulatory instruments", Law and Policy, Vol. 17, no. 3, pp. 256-281.

Grabosky, P.N. (1996), "The future of crime control", Trends and Issues in Crime and Criminal Justice, no. 63.

Hesseling, R. (1994), "Displacement: A review of the empirical literature", Crime Prevention Studies, Vol. 3, pp. 197-230.

Hutter, B. (1997), Compliance: Regulation and Environment, Oxford University Press, Oxford.

Hutter, B. (2001), Regulation and Risk, Oxford University Press, Oxford. 
Hutter, B. \& Power, M. (2000), Risk Management and Business Regulation, Centre for Analysis of Risk and Regulation, London School of Economics and Political Science, London.

Johnston, L. (2000), Policing Britain: Risk, Security and Governance, Longman, Harlow.

International Narcotics Control Board (2004), Precursors and Chemicals Frequently Used in the Illicit Manufacture of Narcotic Drugs and Psychotropic Substances. Report of the International Narcotics Control Board for 2003 on the Implementation of Article 12 of the United Nations Convention against Illicit Traffic in Narcotic Drugs and Psychotropic Substances of 1988, United Nations, New York.

Kleiman, M.A.R. \& Young, R.M. (1995), "The factors of production in retail drug dealing", Urban Affairs Review, Vol. 30, no. 5, pp. 730-748.

Lint, W.D. (2003), "Keeping open windows: Police as access brokers", British Journal of Criminology, Vol. 43, pp. 379-397.

Mazerolle, L.G., Roehl, J. \& Kadleck, C. (1998), “Controlling social disorder using civil remedies: Results from a randomized field experiment in Oakland, California", Crime Prevention Studies, Vol. 9, pp. 141-159.

Mazerolle, L. \& Ransley, J. (2005), Third Party Policing, Cambridge University Press, New York.

McEwen, T. et al. (2002), Combating Methamphetamine Laboratories and Abuse, Office of Community Orientated Policing Services, Washington, DC. Available online at: http://www. cops.usdoj.gov/mime/open.pdf?Item $=776$

National Drug Intelligence Center (2003), Chemicals Commonly Used in Methamphetamine Production, National Drug Intelligence Center, Washington, DC.

New Zealand Customs Service (2002), Review of Customs Drug Enforcement Strategies 2002: Project Horizon Outcome Report, New Zealand Customs Service, Wellington. Available online at: www.customs.govt.nz

Office on Drugs and Crime (2003), Ecstasy and Amphetamines: Global Survey, 2003, United Nations Office on Drug and Crime, New York.

Office on Drugs and Crime (2004), World Drugs Report, United Nations Office on Drug and Crime, New York.

O'Malley, P. (1992), “Risk, power and crime prevention”, Economy and Society, Vol. 21, no. 3, pp. $252-275$.

Osborne, S. \& Gaebler, T. (1992), Reinventing Government: How the Entrepreneurial Spirit is Transforming the Public Sector, Addison-Wesley, Reading, MA.

Peoria Journal Star (2004), "US IL: Parties collaborating to combat meth use", Peoria Journal Star, 23 August. Available online at: http://www.mapinc.org/drugnews/v04.n1204.a10.html (accessed 13 December 2004).

Parker, C. (2002), The Open Corporation: Effective Self-regulation and Democracy, Cambridge University Press, Cambridge.

Parker, C. \& Braithwaite, J. (2003), "Regulation”, in: Cane, P. \& Tushnet, M. (eds) The Oxford Handbook of Legal Studies, Oxford University Press, Oxford.

Rose, N. \& Miller, P. (1992), "Political power beyond the state: Problematics of government", British Journal of Sociology, Vol. 43, no. 2, pp. 173-205.

Scott, M.S. (2002), Clandestine Drug Labs, Problem Oriented Guides for Police Series 16, US Department of Justice, Washington, DC. Available online at: http://www.cops.usdoj.gov/pdf/ e12011406.pdf

Schneider, S., Beare, M. \& Hill, J. (2000), Alternative Approaches to Combating Transnational Crime, KPMG, Toronto.

Shearing, C. (1993), “A constitutive conception of regulation", in: Grabosky, P. \& Braithwaite, J. (eds) Business Regulation and Australia's Future, Australian Institute of Criminology, Canberra. 
Steel, P. (2003), Study of Clandestine Drug Laboratories. Report produced for the Winston Churchill Memorial Trust of Australia, the Donald Mackay Churchill Fellowship study tour to the United States (unpublished).

United Nations Drug Control Program (UNCDP) (1996), Amphetamine-type Stimulants: A Global Review, UNCDP, Vienna.

Van de Bunt, H.G. \& Van der Schoot, C.R.A. (2003), Prevention of Organised Crime: A Situational Approach, Boom Juridiche uitgevers, Justitie, Amsterdam.

Victorian Drugs and Crime Prevention Committee (2004), Inquiry into Amphetamine and Party Drug Use in Victoria, Final Report, Victorian Drugs and Crime Prevention Committee, Victoria, Australia. Available online at: http://www.parliament.vic.gov.au/dcpc/.

Wilkins, C. (2002), "Designer amphetamines in New Zealand: Policy challenges and initiatives", Social Policy Journal of New Zealand, Vol. 19, pp. 14-28. 